\title{
Quality of Life of Mothers of Brazilian Children with Congenital Zika Virus Syndrome and Associated Factors
}

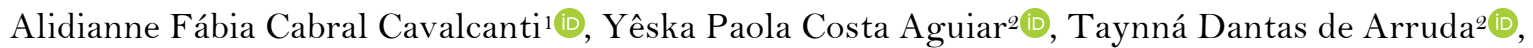 \\ Adriana Suely de Oliveira Melo ${ }^{3}$, Alessandro Leite Cavalcanti ${ }^{1}$, Sérgio d’Ávila1이
}

'Department of Dentistry, State University of Paraíba, Campina Grande, PB, Brazil.

${ }^{2}$ School of Dentistry, State University of Paraíba, Araruna, PB, Brazil.

${ }^{3}$ School of Medicine, Federal University of Campina Grande, Campina Grande, PB, Brazil.

Correspondence: Alidianne Fábia Cabral Cavalcanti, Universidade Estadual da Paraíba, Departamento de Odontologia, Rua das Baraúnas, 351, Bairro Universitário, Campina Grande, PB, Brazil. 58429-500. E-mail: alidianne.fabia@gmail.com

Academic Editor: Wilton Wilney Nascimento Padilha

Received: 05 April 2021 / Review: 29 June 2021 / Accepted: 05 July 2021

How to cite: Cavalcanti AFC, Aguiar YPC, Arruda TD, Melo ASO, Cavalcanti AL, d'Ávila S. Quality of life of mothers of brazilian children with congenital Zika virus syndrome and associated factors. Pesqui Bras Odontopediatria Clín Integr. 2021; 2 1:e0071. https://doi.org/10.1590/pboci.2021.120

\begin{abstract}
Objective: To evaluate the quality of life of mothers of Brazilian children with congenital Zika virus syndrome (CZS) and associated factors. Material and Methods: This cross-sectional study assessed the quality of life (QoL) of 65 mothers of children diagnosed with CZS using the WHOQOL-bref questionnaire. Information related to mothers and children's characteristics and aspects of QoL (physical, psychological, social and environment domains) was collected. Data were presented using descriptive and inferential statistics. Associations between independent variables and quality of life outcome were carried out through bivariate analyses, adopting a 5\% significance level. Results: The "physical" domain showed the highest score $(65.98 \pm 17.62)$, while the "environment" domain showed the lowest score $(48.55 \pm 14.75)$. The quality of life for the physical domain was associated with maternal schooling and child's sex, while the psychological domain was associated with family income and child's sucking difficulty. Conclusion: Socioeconomic characteristics and comorbidities were associated with mothers' QoL. Knowledge of QoL determinants and their impact on different dimensions of life can serve as a guide for interventions aimed at improving the QoL of this population.
\end{abstract}

Keywords: Disabled Children; Microcephaly; Zika Virus Infection; Child Care; Mothers; Quality of Life. 


\section{Introduction}

Congenital Zika virus syndrome (CZS) includes the entire spectrum of manifestations observed in children exposed to the Zika virus (ZIKV) even during the gestational period [1]. Abnormalities can be detected at birth or appear during the first [2,3] or second year of life, with outcomes associated with this condition appearing in the following years [4].

Many infants have less evident deficiencies at birth, which become visible over time, as the ZIKV replication in the infant brain continues after delivery [5], and the brain growth of pre-exposed children may show a slowdown [6]. Thus, episodes of microcephaly that develop after birth have been identified [7]. In addition, infants who initially had head circumference in the pre-established normality range may develop microcephaly in the postnatal period, as well as brain abnormalities consistent with CZS. Therefore, microcephaly diagnosed at birth is not a necessary characteristic of the condition since it can be verified a posteriori [6].

Microcephaly corresponds to a clinical finding characterized by a change in the occipito-frontal head circumference, which is shown to be $\geq 2$ standard deviations (SD) below the standard of curves appropriate for gestational age and sex of infants. According to the protocol in force in Brazil, the parameter adopted for the diagnosis of microcephaly in newborns with 37 or more weeks of gestation corresponds to a diameter $\leq 31.9 \mathrm{~cm}$ for males and $\leq 31.5 \mathrm{~cm}$ for females. The severe subtype is defined by values $>3 \mathrm{SD}$ below the mean [8].

Electromyography studies and brain images of syndromic children identified the presence of neurological lesions involving the central and peripheral nervous system, with effects on the musculoskeletal system, such as hip dysplasia, subluxation of large joints and abnormal posture of extremities, in addition to hearing and ophthalmological alterations [9]. The presence of hypertonia, hemiparesis, extrapyramidal movements, exaggerated primitive reflexes, abnormal posture, epileptic seizures, dysphagia, and irritability were also verified [6, 9-11].

Behavioral aspects with multiple vulnerabilities, such as severe irritability, including almost constant crying, inability to be calmed by the caregiver [10], abnormal sleep patterns [12], and practice of self-injury [13], were also reported, showing the extremely limited functional abilities of these children. Consequently, daily activities are compromised and the need for care will become mandatory throughout life [4].

Therefore, it is understood that families of children with CZS will be affected in many ways, as it is a condition of complex nature, surrounded by obscurities regarding the totality and severity of comorbidities. Similarly, the knowledge of professionals who assist these children, although in constant improvement, is still limited, especially regarding the course of the disease and therapeutic options; in addition, the lack of social support and the high economic costs involved in the task of caring can, together with stress, anxiety, and depression, have adverse effects on the well-being and QoL of family members [14].

Given the lack of similar studies and the theme's relevance, this study aimed to assess the QoL of mothers of children with CZS assisted in two specialized centers in Brazil and investigate associated factors.

\section{Material and Methods}

\section{Study Design and Participants}

This cross-sectional study was conducted in a city in northeastern Brazil with an estimated population of 407,472 people, a Human Development Index of 0.72, and a Gini Coefficient of 0.56 [15].

To integrate the main group (G1 - mothers of children with CZS), mothers of children diagnosed with growth and development changes related to ZIKV infection were recruited in two health centers. 
The following inclusion criteria were established: a) being 18 years of age or older; b) not having previous history of treatment for psychiatric disorders; and c) responding at least $80 \%$ of QoL-related questions. Among the 79 mothers identified, 65 participated in the survey, with a response rate of $82.2 \%$.

Mothers of children without physical and / or intellectual disabilities, but with a socioeconomic profile similar to those allocated in G1, were selected from public primary health care services to compose a comparison group (G2 - mothers of children without disabilities). The following criteria were established between members of groups (in the 1:1 proportion): a) maternal age; b) family income; c) being an exclusive user of the public health system; d) primary caregiver of the child; d) absence of any physical and psychiatric comorbidities; e) infant's sex. Mothers who lived in the same household as the child were defined as primary caregivers, responsible for continuous care [16]. In this way, a total of 65 mothers composed the G2.

Characterization of Mothers and Children with CZS

A questionnaire was used to collect information regarding maternal socioeconomic indicators (age, marital status, schooling and monthly family income), child's profile (sex and age), behavioral characteristics (occurrence of bruxism and self-mutilation), and the CZS spectrum (microcephaly at birth and severity, visual and auditory impairment, musculoskeletal disorders, seizures, irritability, sucking and swallowing difficulty).

\section{WHOQOL-bref}

WHOQOL-bref was used to assess QoL. It is a generic instrument derived from WHOQOL-10O and developed by the Quality of Life Group of the World Health Organization [17]. The Brazilian version, translated and validated at the WHOQOL Center for Brazil, has similar psychometric properties to those obtained with the multicenter study sample [18]. WHOQOL-bref has 26 questions, two general (one addressing QoL self-assessment and the other satisfaction with health) and the remaining 24 items are divided into four domains: 1) Physical, 2) Psychological, 3) Social and 4) Environment. Responses are recorded on a five-point Likert scale, with higher scores indicating higher QoL. Scores were converted into a scale from o to 100 and responses referred to situations of two weeks prior to the time of the interview.

Data were collected from August 2017 to August 2018 through a structured, face-to-face interview conducted by a single researcher (AFCC). For mothers allocated to G1 group, information was collected in a care room at reference centers. In contrast, for mothers belonging to G2 group, home visits were carried out.

\section{Data Analysis}

Initially, descriptive analysis was performed for sample characterization; thus, absolute and percentage frequencies were calculated for categorical variables, while measures of central tendency (mean and standard deviation) were estimated for quantitative variables. Data normality and variance homogeneity assumptions were tested using the Kolmogorov-Smirnov and Levene tests, respectively. Finally, the t-test for independent samples was used to compare means of total scores and WHOQOL-bref domains as a function of established groups ( $\mathrm{G}_{1}$ and $\mathrm{G}_{2}$ ). The power of the test for the comparison of means was greater than $80 \%$, considering the total score.

Associations between explanatory variables (mother and child characteristics) and QoL outcome of mothers in Group 1 were examined using the Chi-square and Fisher's Exact tests. In this case, the dependent variable was categorized as "O" = low QoL and "1" = high QoL, based on the average score observed in each domain [19]. The significance level was set at 5\%, and all analyses were performed using SPSS (Statistical Package for the Social Sciences for Windows - version 21.0). 


\section{Results}

Among mothers, it was observed that age ranged from 18 to 48 years, with an average of $27.72( \pm$ 6.66), with the most frequent age group being from 18 to 28 years (55.4\%). In addition, most mothers had a partner $(53.8 \%)$, had more than eight years of schooling (61.5\%), reported monthly income higher than one minimum wage $(55.6 \%)$, and $83.1 \%$ had been contemplated with some social benefit arising from federal government strategies (Table 1).

Table 1. Socioeconomic characterization of mothers of children with CZS.

\begin{tabular}{|c|c|c|}
\hline Variables & $\mathbf{N}$ & $\%$ \\
\hline \multicolumn{3}{|l|}{ Age group - In years [65] } \\
\hline 18 to 28 & 36 & 55.4 \\
\hline 28 or more & 29 & 44.6 \\
\hline \multicolumn{3}{|l|}{ Marital status [65] } \\
\hline With partner & 35 & 53.8 \\
\hline Without partner & 30 & 46.2 \\
\hline \multicolumn{3}{|l|}{ Schooling $[65]$} \\
\hline$\geq 8$ years & 40 & 61.5 \\
\hline$<8$ years & 25 & 38.5 \\
\hline \multicolumn{3}{|l|}{ Monthly family income [63] } \\
\hline$>1$ Minimum wage & 35 & 55.6 \\
\hline$<1$ Minimum wage* & 28 & 44.4 \\
\hline \multicolumn{3}{|l|}{ Social benefit $[65]$} \\
\hline Yes & 54 & 83.1 \\
\hline No & 11 & 16.9 \\
\hline
\end{tabular}

Children were predominantly male (55.4\%) and over 23 months old (61.5\%). Concerning aspects of the syndrome, it was found that $84.4 \%$ of children had reduction in head circumference, with predominance of the severe subtype (64.8\%). Other clinical findings revealed the occurrence of visual (89.0\%) and auditory $(17.0 \%)$ and musculoskeletal disorders $(95.4 \%)$, seizures $(84.6 \%)$ and excessive irritability $(44.6 \%)$, in addition to the maternal report of difficulties related to sucking (35.0\%) and swallowing (84.6\%). Furthermore, the practice of self-injury, through bites, was frequent among children (60.0\%), as well as the parafunctional habit of bruxism (26.2\%) (Table 2).

Table 2. Characterization of children and the CZS spectrum.

\begin{tabular}{|c|c|c|}
\hline Variables & $\mathbf{N}$ & $\%$ \\
\hline \multicolumn{3}{|l|}{ Sex [65] } \\
\hline Female & 29 & 44.6 \\
\hline Male & 36 & 55.4 \\
\hline \multicolumn{3}{|l|}{ Age group - In months [65] } \\
\hline$\leq 23$ & 25 & 38.5 \\
\hline 24 or more & 40 & 61.5 \\
\hline \multicolumn{3}{|l|}{ Microcephaly at birth $[64]$} \\
\hline No & 10 & 15.6 \\
\hline Yes & 54 & 84.4 \\
\hline \multicolumn{3}{|l|}{ Severity of microcephaly [54] } \\
\hline Mild & 19 & 35.2 \\
\hline Severe & 35 & 64.8 \\
\hline \multicolumn{3}{|l|}{ Visual impairment [64] } \\
\hline No & 07 & 11.0 \\
\hline Yes & 57 & 89.0 \\
\hline \multicolumn{3}{|l|}{ Auditory impairment [59] } \\
\hline No & 49 & 83.0 \\
\hline
\end{tabular}




\begin{tabular}{|c|c|c|}
\hline Yes & 10 & 17.0 \\
\hline \multicolumn{3}{|c|}{ Musculoskeletal disorders [65] } \\
\hline No & O3 & 4.6 \\
\hline Yes & 62 & 95.4 \\
\hline \multicolumn{3}{|c|}{ Seizures [65] } \\
\hline No & 10 & 15.4 \\
\hline Yes & 55 & 84.6 \\
\hline \multicolumn{3}{|c|}{ Irritability [65] } \\
\hline No & 36 & 55.4 \\
\hline Yes & 29 & 44.6 \\
\hline \multicolumn{3}{|c|}{ Sucking difficulty [63] } \\
\hline No & 41 & 65.0 \\
\hline Yes & 22 & 35.0 \\
\hline \multicolumn{3}{|c|}{ Swallowing difficulty [65] } \\
\hline No & 10 & 15.4 \\
\hline Yes & 55 & 84.6 \\
\hline \multicolumn{3}{|c|}{ Self injury [65] } \\
\hline No & 39 & 60.0 \\
\hline Yes & 26 & 40.0 \\
\hline \multicolumn{3}{|c|}{ Bruxism [65] } \\
\hline No & 48 & 73.8 \\
\hline Yes & 17 & 26.2 \\
\hline
\end{tabular}

Comparison of Scores of WHOQOL-bref Domains between G1 and G2 Groups

Regarding QoL of mothers in G1 and G2 groups, the mean scores of the WHOQOL-bref domains are shown in Table 3. It was observed that the physical and environment domain reached, for both groups, the highest $\left(\mathrm{G}_{1}=65.98\right.$ and $\left.\mathrm{G}_{2}=75.05\right)$ and lowest scores $\left(\mathrm{G}_{1}=48.55\right.$ and $\left.\mathrm{G} 2=60.63\right)$, respectively. The QoL of mothers of children with CZS was significantly lower than that of mothers of children without disabilities $(\mathrm{p}<0.05)$ in the Physical, Psychological and Environment domains.

Table 3. Comparison of WHOQOL-bref scores between mothers of children with CZS (G1) and mothers of children without disabilities (G2).

\begin{tabular}{|c|c|c|c|c|}
\hline WHOQOL-bref & $\begin{array}{c}\text { G1 } \\
\text { Mean (SD) }\end{array}$ & $\begin{array}{c}\text { G2 } \\
\text { Mean (SD) }\end{array}$ & p-value* & Effect Size \\
\hline Physical & $65.98( \pm 17.62)$ & $75.05( \pm 13.66)$ & 0.002 & 0.58 \\
\hline Psychological & $59.93( \pm 17.90)$ & $70.90( \pm 14.71)$ & $<0.001$ & 0.67 \\
\hline Social & $64.87( \pm 20.96)$ & $66.66( \pm 20.35)$ & 0.626 & 0.09 \\
\hline Environment & $48.55( \pm 14.75)$ & $60.63( \pm 16.79)$ & $<0.001$ & 0.76 \\
\hline Total & $80.18( \pm 13.22)$ & $89.43( \pm 11.70)$ & $<0.001$ & 0.74 \\
\hline
\end{tabular}

Factors Associated with QoL of Mothers of Children with CZS

Based on the average of each of the four domains, G1 participants were divided into low and high QoL categories and bivariate analysis was performed. It was found that QoL for the physical domain was associated with maternal schooling and child's sex, while psychological domain was associated with family income and sucking difficulty. However, in the social and environment domains, there was no association with any of the predictor variables (Table 4 ).

Table 4. Association between predictor variables and WHOQOL-bref domains.

\begin{tabular}{|c|c|c|c|c|}
\hline \multirow{2}{*}{ Variables } & \multicolumn{4}{|c|}{ Domains } \\
\hline & Physical & Psychological & Social & Environment \\
\hline ners's Characteristics & & & & \\
\hline Age Group & 0.594 & 0.174 & 0.798 & 0.975 \\
\hline
\end{tabular}




\begin{tabular}{|c|c|c|c|c|}
\hline Marital Status & 0.758 & 0.108 & 0.969 & 0.233 \\
\hline Schooling & 0.033 & 0.388 & 0.905 & 0.937 \\
\hline Monthly Family Income & 0.192 & 0.032 & 1.000 & 0.651 \\
\hline Social Benefit & 0.467 & 0.699 & 0.861 & $0.742^{*}$ \\
\hline \multicolumn{5}{|l|}{ Children's Characteristics } \\
\hline Sex & 0.041 & 0.174 & 0.447 & 0.689 \\
\hline Microcephaly at Birth & $0.494^{*}$ & 0.204 & 0.999 & $0.480^{*}$ \\
\hline Severity of Microcephaly & 0.110 & 0.933 & 0.799 & 0.627 \\
\hline Visual Impairment & $1.000^{*}$ & $1.000^{*}$ & $0.689^{*}$ & $0.442 *$ \\
\hline Auditory Impairment & 0.768 & $0.506^{*}$ & 0.678 & $0.488^{*}$ \\
\hline Musculoskeletal Disorders & $0.084^{*}$ & $0.114^{*}$ & $0.705^{*}$ & $0.582^{*}$ \\
\hline Seizures & $0.491^{*}$ & $0.511^{*}$ & $0.495^{*}$ & 0.710 \\
\hline Sucking Difficulty & 0.087 & 0.043 & 0.237 & 0.237 \\
\hline Swallowing Difficulty & $0.491^{*}$ & $0.733^{*}$ & $1.000^{*}$ & $1.000^{*}$ \\
\hline Self-Multilation & 0.760 & 0.156 & 0.261 & 0.476 \\
\hline Bruxism & 0.740 & 0.835 & 0.700 & 0.422 \\
\hline
\end{tabular}

*Fisher's exact.

\section{Discussion}

The QoL of those who provide care to the child population has been extensively investigated [19-26], but studies with caregivers of children with CZS are scarce. Thus, to date, there are few reports in the literature about the impact of this condition on the quality of life of parents or caregivers [27,28].

In this research, the QoL of 65 mothers of children with clinical findings related to ZIKV infection was analyzed. It was evident that mothers were responsible for providing daily care to their children, which is similar to results from previous investigations, which showed a higher prevalence of maternal care directed to children with diverse conditions [22,24,25].

Many challenges are linked to the task of caring for children with disabilities since the stress arising from emotional and physical demands causes changes in the lifestyle of family members due to the imposition of the burden of care [29-31]. Thus, it could be concluded that caring for children with CZS becomes even more complex as it is a condition that includes multiple comorbidities, which in most cases cause total dependence of children in relation to their parents.

In this context, assuming that all facets of primary caregivers' lives can be affected by the child's disability [32], the results of this study demonstrated that the QoL of mothers of children with CZS reached significantly lower scores when compared to that of mothers of healthy children. This finding of reduced quality of life was consistent with previous findings [27].

Approximately three years after the change in the Brazilian epidemiological pattern of live births with neurological disorders resulting from CZS, challenges are still present in multiple ways since children have grown, but their development is incompatible with chronological age and evolution remains uncertain, given the magnitude of functional limitations. Therefore, the impact on the mothers' QoL becomes evident.

The mean scores of domains assessed by WHOQOL-bref pointed out that the mothers' QoL is highly compromised, mainly in the environment domain. On the other hand, the domain with the best result was the physical, which may be a consequence of mothers' age, which are mostly young, corroborating previous findings [25]. Other studies that have used the same instrument also found that the physical and environmental domains were those with the lowest and greatest impact, respectively [19,24,25].

Even with the highest score, the physical domain was associated with maternal schooling. Therefore, in the first analysis, it is assumed that low educational level and other factors have influenced dissatisfaction about the ability to work and perform daily activities. 
Still, in relation to this domain, the association found with the child's sex should be highlighted, which has been previously described as a factor capable of influencing the quality of life outcome [25]. Although the study was conducted with parents of children with a health condition (hearing deficiency) different from that analyzed here (CZS), it was observed that having a male child with that condition and being satisfied with the social support received were items associated with better QoL in the physical domain [25]. In the present investigation, it is assumed that there is a difference between the number of clinical manifestations, their level of severity and the child's sex.

Regarding the psychological domain, it has been previously described that mothers of newborns diagnosed with CZS had significantly lower scores in the psychological domain of the WHOQOL-BREF compared to mothers of healthy infants [27], and this finding is confirmed after one year [28] and also in this research, which can be justified by obscurities that still surround the prognosis of the condition presented by these children.

Different levels of psychological distress were also observed in mothers of children who were born prematurely [26], with Down syndrome [20], osteogenesis [22] and cerebral palsy (CP) [24]. Caregivers of children with CP provide lifelong care for their children [33] so that they face different long-term stressors, causing them to present mental symptoms and parental suffering, which in turn affect their QoL [24] in a way similar to that for mothers of children with CZS.

Family income was shown to be associated with the psychological domain. For this result, it was suggested, as an explanatory hypothesis, the fact that a significant portion of mothers did not perform paid activity. The financial limitation is a problem that causes severe psychological impact, since the countless demands of their children, such as intensive therapies with physiotherapists and occupational therapists, specific diets, installation of orthoses and surgical interventions, will depend, almost entirely, on the public health system in force in Brazil.

Another possibility of assistance to these children is the use of services provided by specialized centers present in the municipality, such as the "Professor Joaquim Amorim" Research Institute, composed of health professionals from the most diverse areas of knowledge, who work together with the purpose of not only seeking for evolution and deeper knowledge about CZS, but also assisting children and their families free of charge.

An extremely relevant finding for the psychological domain and its association with the sucking difficulty presented by the child was observed. Cavalcanti [32] reported that children with CZS exhibited changes in muscle tone in the lower third of the face, causing direct interference with the sucking reflex. Thus, it is believed that breast or artificial feeding of a child with this limitation constitutes an arduous and frustrating task for the maternal figure, thus causing psychological repercussions.

Regarding the domain that involves social relationships, the importance of social support is seen as a strategy that can help parents / caregivers to deal with the needs of a child with a disability [34]. Formal social support can come from sources such as health services and even from the team of professionals involved in care [35]. In turn, informal support that includes the help of family members and friends is a modality that must be present [35].

The municipality in which this study was conducted provides conditions for assistance so that mothers can exchange information and share experiences. In addition, weekly workshops with psychologists and daily dialogue between mothers and professionals via social networks are also offered. Thus, the possibility of 
acquiring new information is constant and the improvement of skills that will be converted into improvements in the care provided to children with CZS.

The fourth and last domain, the environment, was the one with the lowest average, showing that mothers need, in addition to information, actions that involve the other aspects of this domain. Some services, such as nursing homes, means of transport for access to health services and financial support, can improve QoL regarding the environment domain [20]. In Brazil, the inclusion of families in the federal government's social programs and access to the Continued Cash Benefit (BPC) for children with CZS [36] was regulated by Decree No. 58 of 2016, and more recently, with the publication of Law No. 13.985, the granting of a special and lifetime pension was established [37].

The study presented a cross-sectional design, which prevented cause and effect associations. Therefore, the possibility of monitoring possible changes in the scores of domains should be considered by conducting longitudinal studies as children grow and new scenarios are established.

Finally, through this study and the use of the WHOQOL-bref, it was possible to perceive the life context of the population segment of mothers of children with CZS. In addition to the individual characteristics of mothers and their children, physical, psychological, social and environment aspects that composed the structure of the instrument used provided depth in the analysis of the set of determinants. Consequently, data will support the decision-making on which specific strategies can be implemented to improve the QoL of these people.

\section{Conclusion}

The QoL of mothers of children with CZS was more intensely compromised in aspects related to the environment domain, having been influenced by socioeconomic characteristics and comorbidities exhibited by children in the physical and psychological domains.

\section{Authors' Contributions}

\begin{tabular}{|c|c|c|}
\hline $\mathrm{AFCC}$ & (D) https://orcid.org/0000-0002-7779-2478 & $\begin{array}{l}\text { Methodology, Formal Analysis, Investigation, Data Curation, Writing - Original Draft and } \\
\text { Writing - Review and Editing. }\end{array}$ \\
\hline YPCA & (iD) https://orcid.org/0000-0003-4756-9096 & Investigation and Data Curation. \\
\hline TDA & (iD) https://orcid.org/0000-0002-9093-8398 & Data Curation and Writing - Review and Editing. \\
\hline ASOM & (i) https://orcid.org/0000-0002-8575-544X & Data Curation and Visualization. \\
\hline ALC & (D) https://orcid.org/0000-0003-3572-3332 & $\begin{array}{l}\text { Conceptualization, Methodology, Formal Analysis, Writing - Review and Editing, Supervision } \\
\text { and Project Administration. }\end{array}$ \\
\hline & https://orcid.org/0000-0002-7836-896X & Conceptualization, Methodology, Formal Analysis and Writing - Review and Editing. \\
\hline
\end{tabular}

\section{Financial Support}

The National Council for Scientific and Technological Development (CNPq) - Research Productivity Scholarship (Process 302850 / 2016$3)$.

\section{Conflict of Interest}

The authors declare no conflicts of interest.

\section{Data Availability}

The data used to support the findings of this study can be made available upon request to the corresponding author.

\section{Acknowledgment}

The authors would like to thank the of Professor Joaquim Amorim Neto, Research Institute, and Mrs. Jeime Iara Bezerra de Freitas Leal of the Specialized Center for Rehabilitation. 


\section{References}

[1] Costa F, Sarno M, Khouri R, de Paula Freitas B, Siqueira I, Ribeiro GS, et al. Emergence of congenital Zika syndrome: viewpoint from the front lines. Ann Intern Med 2016; 164(10):689-91. https://doi.org/10.7326/M16-0332

[2] Brasil P, Pereira JP Jr, Moreira ME, Ribeiro Nogueira RM, Damasceno L, Wakimoto M, et al. Zika virus infection in pregnant women in Rio de Janeiro. N Engl J Med 2016; 375(24):232 1-34. https://doi.org/10.1056/NEJMoa 1602412

[3] Soares de Souza A, Moraes Dias C, Braga FD, Terzian AC, Estofolete CF, Oliani AH, et al. Fetal infection by zika virus in the third trimester: report of 2 cases. Clin Infect Dis 2016; 63(12):1622-5. https://doi.org/10.1093/cid/ciw613

[4] Wheeler AC. Development of infants with congenital Zika syndrome: What do we know and what can we expect? Pediatrics 2018; 141(Suppl 2):S154-S160. https://doi.org/10.1542/peds.2017-2038D

[5] Bhatnagar J, Rabeneck DB, Martines RB, Reagan-Steiner S, Ermias Y, Estetter LB, et al. Zika virus RNA replication and persistence in brain and placental tissue. Emerg Infect Dis 2017; 23(3):405-14. https://doi.org/10.3201/eid2303.161499

[6] van der Linden V, Pessoa A, Dobyns W, Barkovich AJ, Júnior HV, Filho EL, et al. Description of 13 infants born during October 2015-January 2016 with congenital Zika virus infection without microcephaly at birth - Brazil. MMWR Morb Mortal Wkly Rep 2016; 65(47):1343-8. https://doi.org/10.15585/mmwr.mm6547e2

[7] Pessoa A, van der Linden V, Yeargin-Allsopp M, Carvalho MDCG, Ribeiro EM, Braun KVN, et al. Motor abnormalities and epilepsy in infants and children with evidence of congenital Zika virus infection. Pediatrics 2018; 141(Suppl 2):S167-S179. https://doi.org/10.1542/peds.2017-2038f

[8] Brasil. Ministério da Saúde. Secretaria de Atenção à Saúde. Protocolo de Atenção à Saúde e Resposta à Ocorrência de Microcefalia. Plano Nacional de Enfrentamento à Microcefalia. Brasília: Ministério da Saúde; 2016. [In Portuguese].

[9] van der Linden V, Filho EL, Lins OG, van der Linden A, Aragão Mde F, Brainer-Lima AM, et al. Congenital Zika syndrome with arthrogryposis: retrospective case series study. BMJ 2016; $354: 13899$. https://doi.org/10.1136/bmj.i3899.

[10] Moura da Silva AA, Ganz JS, Sousa PD, Doriqui MJ, Ribeiro MR, Branco MD, et al. Early Growth and Neurologic Outcomes of Infants with Probable Congenital Zika Virus Syndrome. Emerg Infect Dis 2016; 22(11):1953-1956. https://doi.org/10.3201/eid2211.160956.

[11] Moore CA, Staples JE, Dobyns WB, Pessoa A, Ventura CV, Fonseca EB, et al. Characterizing the Pattern of Anomalies in Congenital Zika Syndrome for Pediatric Clinicians. JAMA Pediatr 2017; 171(3):288-295. https://doi.org/10.1001/jamapediatrics.2016.3982.

[12] Carvalho MDCG, Miranda-Filho DB, van der Linden V, Sobral PF, Ramos RCF, Rocha MÂW, et al. Sleep EEG patterns in infants with congenital Zika virus syndrome. Clin Neurophysiol 2017; 128(1):204-14. https://doi.org/10.1016/j.clinph.2016.11.004

[13] Siqueira RMP, Santos MTBR, Cabral GMP. Alterations in the primary teeth of children with microcephaly in Northeast Brazil: a comparative study. Int J Paediatr Dent 2018; 2018. https://doi.org/10.1111/ipd.12402

[14] Bailey DB, Ventura LO. The Likely Impact of congenital Zika syndrome on families: considerations for family supports and services. Pediatrics 2018; 141(Suppl 2):S180-S187. https://doi.org/10.1542/peds.2017-2038G

[15] Instituto Brasileiro de Geografia e Estatística (IBGE). Brasil/ Paraíba/ Campina Grande. 2018. Available from: https://cidades.ibge.gov.br/brasil/pb/campina-grande/pesquisa/37/30255 [Accessed on September 23, 2018]. [In Portuguese].

[16] Grover S, Dutt A. Perceived burden and quality of life of caregivers in obsessive-compulsive disorder. Psychiatry Clin Neurosci 2011; 65(5):416-22. https://doi.org/10.1111/j.1440-1819.2011.02240.x

[17] The WHOQOL Group. Development of the World Health Organization WHOQOL-BREF Quality of Life Assessment. Psychol Med 1998; 28(3):551-8. https://doi.org/10.1017/s003329179800666

[18] Fleck MP, Louzada S, Xavier M, Chachamovich E, Vieira G, Santos L, et al. Application of the Portuguese version of the abbreviated instrument of quality life WHOQOL-bref. Rev Saúde Pública 2000; 34(2):178-83. https://doi.org/10.1590/s0034-89102000000200012

[19] Nishida T, Tanaka Y, Sakakibara H. Factors associated with quality of life among mothers rearing 4- and 18-month old infants in Japan. Matern Child Health J 2018; 22(8):1217-25. https://doi.org/10.1007/s10995-018-2493-2

[20] Tekinarslan IC. A comparison study of depression and quality of life in Turkish mothers of children with Down syndrome, cerebral palsy, and autism spectrum disorder. Psychol Rep 2013; 112(1):266-87. https://doi.org/10.2466/21.02.15.PRo.112.1.266-287

[21] Queiroz BM, Alencar NA, Requejo MEP, Antonio AG, Maia LC. Risk factors, perception of caregivers and impact of early childhood caries on quality of life related to oral health. Pesqui Bras Odontopediatria Clín Integr 2015; 15(1):8594. https://doi.org/10.4034/PBOCI.2015.151.10

[22] Vanz, AP, Félix TM, Rocha NS, Schwartz IV. Quality of life in caregivers of children and adolescents with Osteogenesis Imperfecta. Health Qual Life Outcomes 2015; 13:41. https://doi.org/10.1186/s12955-015-0226-4

[23] Carneiro TV, Lucena RB, Ribeiro ILA, Agripino GG, Valença AMG, da Rosa MRD. Quality of life of paediatric oncology patients. Pesqui Bras Odontopediatria Clín Integr 2016; 16(1):457-67. https://doi.org/10.4034/PBOCI.2016.161.48 
[24] Tseng MH, Chen KL, Shieh JY, Lu L, Huang CY, Simeonsson RJ. Child characteristics, caregiver characteristics, and environmental factors affecting the quality of life of caregivers of children with cerebral palsy. Disabil Rehabil 2016; 38(24):2374-82. https://doi.org/10.3109/09638288.2015.1129451

[25] Ramires CMN, Branco-Barreiro FCA, Peluso ETP. Quality of life related factors for parents of children with hearing loss. Ciênc Saúde Coletiva 2016; 21(10):3245-52. https://doi.org/10.1590/1413-812320152110.224720

[26] Moura MR, Araújo CG, Prado MM, Paro HB, Pinto RM, Abdallah VO, et al. Factors associated with the quality of life of mothers of preterm infants with very low birth weight: a 3-year follow-up study. Qual Life Res 2017; 26(5):1349-60. https://doi.org/10.1007/s11136-016-1456-6

[27] Dos Santos Oliveira SJG, de Melo ES, Reinheimer DM, Gurgel RQ, Santos VS, Martins-Filho PRS. Anxiety, depression, and quality of life in mothers of newborns with microcephaly and presumed congenital Zika virus infection. Arch Womens Ment Health 2016; 19(6):1149-51. https://doi.org/10.1007/s00737-016-0654-0

[28] Dos Santos Oliveira SJG, Dos Reis CL, Cipolotti R, Gurgel RQ, Santos VS, Martins-Filho PRS. Anxiety, depression, and quality of life in mothers of newborns with microcephaly and presumed congenital Zika virus infection: a followup study during the first year after birth. Arch Womens Ment Health 2017; 20(3):473-5. https://doi.org/10.1007/s00737-017-0724-y

[29] Carona C, Silva N, Crespo C, Canavarro MC. Caregiving burden and parent-child quality of life outcomes in neurodevelopmental conditions: the mediating role of behavioral disengagement. J Clin Psychol Med Settings 2014; 2 1(4):320-8. https://doi.org/10.1007/s10880-014-9412-5

[30] Khanna AK, Prabhakaran A, Patel P, Ganjiwale JD, Nimbalkar SM. Social, psychological and financial burden on caregivers of children with chronic illness: a cross-sectional study. Indian J Pediatr 2015; 82(11):1006-11. https://doi.org/10.1007/s12098-015-1762-y

[31] Beckung E, Carlsson G, Carlsdotter S, Uvebrant P. The natural history of gross motor development in children with cerebral palsy aged 1 to 15 years. Dev Med Child Neurol 2007; 49(10):751-6. https://doi.org/10.1111/j.1469-8749.2007.00751.x

[32] Cavalcanti AL. Challenges of dental care for children with microcephaly carrying Zika congenital syndrome. Contemp Clin Dent 2017; 8(3):345-6. https://doi.org/10.4103/0976-237X.214553

[33] Medeiros MMD, Martins ML, Gomes LN, Cardoso AMR, Padilha WWN, Cavalcanti AL. Factors associated with the caregivers' perception of the oral health of individuals with cerebral palsy. Pesqui Bras Odontopediatria Clín Integr 2019; 19:e4824. https://doi.org/10.4034/PBOCI.2019.191.139

[34] Tehee E, Honan R, Hevey D. Factors contributing to stress in parents of individuals with autistic spectrum disorders. J Appl Res Intellect Disabil 2009; 22(1):34-42. https://doi.org/10.1111/j.1468-3148.2008.00437.x

[35] Kandel I, Morad M, Vardi G, Press J, Merrick J. The Arab community in Israel coping with intellectual and developmental disability. Sci World J 2004; 4:324-32. https://doi.org/10.1100/tsw.2004.31

[36] Brasil. Ministério do Desenvolvimento Social e Agrário. Portaria nº 58, de 3 de junho de 2016. Dispõe sobre ações articuladas das redes de Assistência Social e Previdência Social na atenção às crianças com microcefalia para o acesso ao Benefício de Prestação Continuada da Assistência Social - BPC. Diário Oficial da União 2016. [In Portuguese].

[37] Brasil. Lei n ${ }^{\circ}$ 13.985, de 7 de Abril de 2020. Institui pensão especial destinada a crianças com Síndrome Congênita do Zika Vírus, nascidas entre $1^{\circ}$ de janeiro de 2015 e 31 de dezembro de 2019, beneficiárias do Benefício de Prestação Continuada (BPC). [In Portuguese ]. 